\title{
CHANGES IN THE REGULATORY BASE OF THE BUDGETARY PROCESS IN MARCH 2013
}

\author{
M.Goldin
}

In March 2013, by Resolution of the Government of the Russian Federation a number of amendments to the procedure for formation and payment of pension accruals was approved; criteria of innovation and high-tech produce were determined by the Order of the Ministry of Industry and Trade.

By Resolution No. 213 of March 16, 2013 on Amendment of Some Acts of the Government of the Russian Federation as Regards Payments by Means of Pension Accruals, such amendments were introduced into a number of acts of the Government of the Russian Federation as modify the rules of investment of pension accruals into individual classes (categories) of assets.

Resolution No. 190 of April 2, 2003 of the Government of the Russian Federation specifies the authorities of the Ministry of Finance of the Russian Federation and the Federal Service for Financial Markets due to coming into effect in July 2012 of Federal Law No. 360-FZ of November 30, 2011 on the Procedure for Financing of Payments by Means of Pension Accruals which sets the procedure for payment of pension accruals in the form of "term pension benefit". Accordingly, the function of approval of the composition of the necessary expenditures of the asset manager as regards investment of pension accruals is assigned to the authorities of the Ministry of Finance, while that of approval of the procedure, form and the period for provision of reporting by the entities of the relations in formation and investment of funds of pension accruals as regards funds of the payable reserve and pension accruals of the insured persons in respect of which term pension benefit is determined, to the Federal Service for Financial Markets.

In Resolution No. 379 of June 30, 2003 of the Government of the Russian Federation, the following provisions have been amended.

Pension accruals can be invested not only in bonds issued on behalf of the Russian Federation, constituent entities of the Russian Federation and municipal entities, but also in bonds of other Russian issuers provided that the above bonds have not become mature. It is to be reminded that according to the Federal Law on the Securities Market the issuer is recognized a legal entity, executive state authority and local government which are responsible on their own behalf or on behalf of a public entity to securities holders for fulfillment of the rights vested by the above securities.

It was determined that the maximum share of funds in the national currency of the Russian Federation and foreign currency in accounts with credit institutions, as well as deposits in the national currency of the Russian Federation and foreign currency with credit institutions (aggregately) in the investment portfolio formed by means of funds transferred by the Pension Fund of the Russian Federation in trust management to asset managers (AM) and investment portfolio of a non-government pension fund which carries out mandatory pension insurance should amount maximum to $80 \%$.

At the same time, excluded from Resolution No. 231 of the Government of the Russian Federation was a requirement to the maximum share in investment portfolios of asset managers and non-government pension funds of bonds of Russian issuers whose obligations are guaranteed by the Russian Federation, as well as bonds whose issuer was assigned the rating of long-term creditworthiness as regards obligations in the national currency of the Russian Federation or foreign currency by one of the following international rating agencies - Fitch-Ratings, Standard \& Poor's and Moody's Investors Service - accredited in accordance with the procedure set by a federal executive authority in charge of financial markets; the level of the above rating should not be below the sovereign rating of the Russian Federation as regards obligations in the national currency of the Russian Federation or foreign currency (the relevant rating is be assigned by at least one of the above rating agencies): 
By amendments to Resolution No.500 of May 21, 2012 of the Government of the Russian Federation, it was determined that the amount of payment, composition of the required costs related to investment of pension accruals of the insured persons in respect of whom a term pension benefit is established, as well as the amount of remuneration of a state asset manager under relevant agreements on trust management of the above funds are set by the same rules that regulate the above issues in respect of other pension resources which are accounted for in the payable reserve.

Order No. 1618 of November 1, 2012 of the Ministry of Industry and Trade on Approval of the Criteria of Attribution of Goods, Jobs and Services to the Innovation Produce and (or) HighTech Produce by Sectors Related to the Sphere of Activities of the Ministry of Industry and Trade of the Russian Federation specifies the criteria of attribution of goods, jobs and services to the innovation produce and (or) high-tech produce.

The Order was registered under No. 27584 by the Ministry of Justice of the Russian Federation on March 11, 2013.

The Order was approved as a sublegislative act which ensures the effect of the norm of Article 4 (4) of Federal Law No. 223-FZ of July 18, 2011 on Purchases of Goods, Jobs and Services by Individual Types of Legal Entities under which norm the respective criteria are to be established for the purpose of formation of the plan of procurement of innovation and high-tech products.

The following parameters serve as criteria of attribution of goods, jobs and services to innovation products:

1. Consumer properties (including performance parameters) of goods are new ones and (or) excel those (including performance parameters) of goods that were produced earlier;

2. In manufacturing of a product, outputs of $R \& D$ were utilized for the first time;

3. Consumer properties of goods are the upgraded ones as compared to the exiting analogs or, in case of absence of such analogs, there are quality new consumer (functional) parameters, including those which upgrade the competitiveness of the product or a new application mode which permits to expand utilization of the product;

4. In manufacturing of the product, only new or upgraded technological equipment, operating processes or technologies which were not used before in production of that product or new materials permitting to upgrade technical, economic, competitive, ergonomic, consumer and other parameters of the product were used;

5. In carrying out of jobs and rendering of services, R\&D outputs which were not used earlier in fulfillment of such jobs and rendering of services were utilized for the first time;

6. Fulfillment of jobs and rendering of services are related to changes in the production process and utilization of a new or state-of-the-art equipment and/or software and new technologies;

7. The job is done and the service is rendered in the area where similar jobs and services were not utilized before;

8. The job and service are the new ones and they were neither done, nor rendered before;

9. In manufacturing of the product, fulfillment of a job and rendering of services, such outputs of intellectual activities were utilized as are subject to legal protection;

10. In manufacturing of the product, fulfillment of a job and rendering of services, new $R \& D$ and technological decisions were utilized.

Goods, jobs and services are recognized as innovation products if they comply with one or more criteria specified in items 1-10.

The following parameters serve as criteria of attribution of goods, jobs and services to high-tech products:

1. Goods, jobs and services are produced, carried out and rendered, respectively, by enterprises of science-intensive industries;

2. Goods, jobs and services are produced, carried out and rendered, respectively, with utilization of state-of-the-art production equipment, operating procedures and technologies;

3. Goods, jobs and services are produced, carried out and rendered, respectively, with participation of skilled and specially trained personnel.

Goods, jobs and services are recognized as high-tech products if they comply with all the three criteria specified in items $1-3$. 